\title{
Marriage Ceremony in Batak Toba Tribe: Between Consumerism and Purpose of Life
}

\author{
Mangihut Siregar ${ }^{1}$ \\ ${ }^{1}$ Political Science Magister, FISIP, Wijaya Kusuma Surabaya University, Indonesia \\ Correspondence: Mangihut Siregar, Political Science Magister, Wijaya Kusuma Surabaya University, Surabaya, \\ Indonesia. E-mail: msiregar22@yahoo.com
}

Received: December 3, 2019; Accepted: December 20, 2019; Published: December 22, 2019

\begin{abstract}
The marriage ceremony for the Batak Toba tribe is a bond between a man and a woman along with relatives of men and women. Through marriage ceremonies they can enter the dalihan na tolu system, carry out a life cycle, become adults and have the right to enter the Batak lineage (tarombo). Because of the importance of the meaning of the marriage ceremony, the Batak Toba people continue to carry out this tradition.

According to the tradition of the ancient people, the marriage ceremony was carried out simply by mutual cooperation. In accordance with its development, the marriage ceremony changed from simple to consumerism. Consumerism occurs in mindset, behavior and also matter. Consumer behavior is influenced by: globalization, lifestyle, popular culture and a lack of understanding of the meaning of the Batak Toba marriage ceremony.

The phenomenon of consumerism that occurs in the Batak Toba wedding ceremony is very complex because it follows a long procession at a high cost. Although the behavior of consumerism has long been a problem, but in reality they still do and are in a culture of consumerism. The culture of consumerism on the one hand is a problem but on the other hand is an arena to achieve life purpose.
\end{abstract}

Keywords: consumerism, marriage ceremony, purpose of life

\section{Introduction}

The marriage ceremony is a very important thing for the Batak Toba tribe. The marriage ceremony not only combines a man with a woman but has a meaning that is far more important and broad than that where marriage is a bridge to enter the dalihan na tolu system of transition. Through a marriage ceremony, every Batak person is considered to be an adult and can enter the dalihan na tolu system.

In addition to functioning as a bridge to enter the dalihan na tolu diverts, the marriage ceremony also aims to be able to carry out the life cycle, for example welcoming newborn children, marriage, death, entering the house, and others. Families who have not yet been married in a local language called mangadati where they have no right to give or receive adat from others. The marriage ceremony becomes the foundation of every family to be able to carry out all forms of traditional ceremonies contained in the Batak Toba tribe. So important is the marriage ceremony for the Batak Toba people that this tradition is maintained both in the area of origin and overseas.

The practice of marriage ceremonies both in the area of origin and overseas has been filled with consumerism. The nature of consumerism can be seen from the amount of costs spent ranging from hundreds of millions to billions of Rupiah at each wedding ceremony. In addition to the enormous costs, the duration of the ceremony also increased. This phenomenon they are accustomed to do consciously as if it becomes a necessity. Consumerism on the one hand becomes a problem, but on the other hand consumerism is seen as a way to achieve life goals.

\section{Method}

The method used in this research is a qualitative method. The informants studied are not only objects but also as research subjects so that the communication is intersubjective. Researchers attempt to analyze social life by describing the social world from the point of view of informants with a natural background (Martono, 2015:211). This study aims to understand the phenomena experienced by research subjects. The subject's experience can be known holistically through behavior, perception, motivation, action, etc. This research is described in a holistic manner using natural methods (Moleong, 2014: 6). 
Large cities are the researcher's choice for city research including Jakarta, Medan, Surabaya and Bali. In addition to these cities, the study was also conducted in the area of origin, namely Tapanuli, North Sumatra. The reason to choose big cities as research locations is because in that area almost every day a wedding ceremony that is consumerism is held. The reason why the area of origin was also examined is to find out the beginning of the marriage ceremony according to ancient traditions.

This study uses two data sources, namely primary data and secondary data. Primary data obtained from research through the first source in the form of interviews. Interviews were conducted with informants who were guided by interview guidelines and developed during the interview. To support primary data, this research also includes secondary data in the form of documents in the form of books, scientific articles and seminar results.

Primary data were obtained from informants determined by purposive technique. Informants were determined according to criteria relevant to the research topic. The informants chosen in this study are traditional leaders, community leaders, religious leaders, families who have held a marriage ceremony and also the young generation as the successors of the Batak Toba culture.

Data collection techniques carried out by observation, interviews, literature studies and document studies. The data analysis process was carried out since the review of all data collected from various sources through interviews, observations, documents relating to consumerism in the Batak Toba marriage ceremony. Data is read, grouped, categorized and examined for its validity. The next analysis is drawing conclusions and verification. Data presented in a descriptive inductive analytic manner.

\section{Results}

\subsection{The Practice of The Batak Toba Marriage Ceremony}

Batak Toba marriage ceremony practice according to ancient tradition, the ratification of the Batak marriage was carried out only by custom. The parbaringin act as ceremonial leaders through prayer to the spirits of their ancestors or God called Mulajadi na Bolon (Simanjuntak, 2011: 127). The entry of zending into the Tapanuli region on October 7, 1862 which was also made the birthday of the Protestant Batak Christian Huria (HKBP) brought a very big change to the lives of the Batak tribe (Hutauruk, 2011: 4). The ratification of marriage has mixed Christianity and Batak traditions.

The entry of Christianity into Tapanuli has an impact on the practice of the Batak marriage ceremony. The ratification of the ceremony is carried out by two elements, namely religion and tradition. A marriage is not legal if it is not carried out in a religious manner. Conversely, marriages are not perfect if they are not carried out according to the tradition of the Batak tribe or have not been devoted. There is nothing more religiously and traditionally more important than a ceremony, but both are equally important.

The implementation of the Batak Toba marriage ceremony both in the village and in the city is almost the same. This similarity occurs because when Batak people go to other regions, they also carry their traditions. As Pelly (1994: 294) stated, the Batak tribe had a cultural mission to wander to expand their homeland and establish a private kingdom (sahala harajaon). Their cosmology about overseas control was a unity with their homeland. The cultural mission which sees the overseas region as an expansion of the hometown to establish private kingdoms, has implications for traditional ceremonies performed in the overseas area.

In the area of origin, the traditional wedding ceremony was held in the yard of the house. Each house is built in a row and facing each other to form a village. Each huta has a large courtyard for the purpose of carrying out wedding ceremonies, death ceremonies, and other ceremonies. The yard of the house must be large, one of the objectives is to be able to accommodate many people when performing traditional ceremonies.

The procession of the Batak marriage ceremony is carried out with standard stages. The first stage is marhusip. Marhusip is whispering between one person with another person or one party with another party. If a young man and a woman love each other and agree to have a marriage, then the next step is to report the plan to each parent. Marriage for the Batak tribe is not enough to talk about only two people who love each other but must have permission from parents. Each parent will investigate the personality of the prospective son-in-law. If it is suitable, parents follow it up with a marhusip.

Marhusip is a the process of getting to know the parents of men to the parents of the women. At the time of marhusip, they discussed the following matters: number of dowry, number of ulos, place of implementation, date of implementation, number of invitations, etc. relating to the wedding ceremony. The people involved in this activity are close relatives, one to two dongan tubu men, plus one boru. Likewise, the parents of women who accept the families of the men amounted to three to four people. The number of people involved in marhusip is 
very limited in order to maintain the confidentiality of the conversation. If the marriage plan is canceled then the two parties are not so ashamed because it is still very confidential.

The cost spent at the marhusip event is very cheap because the women only prepare coffee and sweet tea. The men bring bread as consumption for five to ten people. Men and women meet each other in relaxed situations. The female family will ask the purpose of the arrival of the male family and the male will explain the purpose of their arrival. If the talks between the two parties are welcomed, then proceed with a very official event called Marhata sinamot.

At present, the implementation of marhusip has experienced a shift. A program that is supposed to be very secret is no secret. The meaning of the marhusip that should have whispered turned into an announcement filled with imagery. Men and women openly do it by inviting dozens to hundreds of people. Inviting many people to watch the marhusip program is common and seems like a must. Bringing many people the aim is to show economic prowess to others. Simplicity shifts to luxury. The shift in the number of people invited and the quality of food served resulted in huge costs. The large number of people present and the luxury of the food menu did not affect the meaning of marhusip. The success of marhusip is measured from the agreement of both parties to follow it up at the next stage, which is then called marhata sinamot.

After the women and the men's family found an agreement at the time of marhusip, then proceed to the official event called Marhata sinamot. Marhata means to speak, sinamot means dowry. In short marhata sinamot is an event to discuss dowry. In practice, at the time of Marhata sinamot, not only the bride price was discussed but also matters relating to the marriage ceremony.

The implementation of marhata sinamot is almost the same as marhusip. The difference is that marhusip is conducted informally and confidentially, whereas marhata sinamot is formal and not confidential. According to ancient tradition, people involved in marhata sinamot are close relatives. They consist of dongan tubu which amounts to two to three people, hula-hula also numbered two to three people, and boru numbered one person. Whereas the number of women was higher because they were added by the representatives of their village friends (dongan sahuta). If the total number of people attending the marhata sinamot program is twenty to thirty people. The men prepare food in the form of cooked rice and pork (lomok-lomok), about $15 \mathrm{~kg}$. The family of the woman provides rice and goldfish about $3 \mathrm{~kg}$. The total cost in the marhata sinamot event spent IDR 5,000,000 to IDR $7,000,000$.

Along with its development, marhata sinamot which was initially attended by 20 people to 30 people turned into hundreds of people. Inviting many people resulted in the cost of implementing marhata sinamot swelling to tens of millions of Rupiah. The more people invited, the more consumption is served. The more consumption that must be served, the greater the cost spent.

The large number of people present at the marhata sinamot did not affect the meaning of the event. The perfection of marhata sinamot is measured by the completeness of the elements of Dalihan na tolu, namely dongan tubu, hula-hula and boru plus dongan sahuta. When this element is represented, then marhata sinamot is perfect. Nowadays the practice of marhata sinamot has shifted. Batak people are influenced by their appearance and eliminate the meaning of marhata sinamot. It is very difficult to distinguish between Marhata sinamot and the marriage ceremony (Mangadati). Both of these activities are equally inviting many people with all the luxuries.

Luxury is a necessity and even a priority. The Batak rate the success of the marhata sinamot is determined by the luxury presented plus the number of people invited. This shift has made the implementation of the marhata sinamot more expensive over time.

The agreement during the marhata sinamot will be held on the peak day of the marriage ceremony. In the morning before the bride and the invitees go to church to hold a religious marriage blessing, they first carry out a sibuhabuhai event. Sibuhabuhai comes from the word buha which means open. Sibuhabuhai means open wealth (hamoraon), honor (hasangapon), and many children (hagabeon) for both parties. These three elements are the life goals of the Batak tribe.

The implementation of marsibuhabuhai is arguably the standard form. The male family provides small pork food (lomok-lomok) together with enough rice, while the female family provides the goldfish. The place for the implementation of marsibuhabuhai must be at the women's house and may not be in the house of the male party. After praying and eating together, both parties went to church to receive Christian blessing. Christian blessing became one with the Batak tribe after European zending entered Tapanuli in 1861.

In addition to reaching hagabeon, hamoraon and hasangapon, sibuhabuhai also means that all events carried out on peak days run smoothly. To achieve this smoothness, it is necessary to intervene in the Lord which they 
originally called Mulajadi na Bolon. Therefore, Sibuhabuhai is a very important and sacred event. In accordance with its development, marsibuhabuhai has experienced many shifts. The meaning of marsibuhabuhai is often interpreted as an ordinary breakfast. The food needed is all ordered through catering services, and the implementation is already in the building not in the house of the woman anymore. This happens due to globalization.

Globalization as said by Piliang (2011: 232) makes individual humans (homo individualist) more selfish than society. Humans are forced to use economic calculations and the nature of mutual cooperation into an illicit tradition. Humans want everything which is fast or practical because in globalization humans are controlled by time and everything which is practical. As a result of this everything which is fast and individualism, the marsibuhabuhai event costs even more. The food needed is not cooked by mutual cooperation, but ordered through catering services. The location of the event which is usually done at the house of the woman moves to a building that requires rent.

In the afternoon, after the wedding blessing in the church was finished, it was time for the top event called mangadati. Mangadati procession is an event to pay off the bride price and not all of it is paid at the time of marhata sinamot. After all the dowry is paid by the man, the woman gives ulos to the man. For the Batak tribe, the balance is always maintained, if someone is given then there must be a reward. When men give meat, women respond by giving fish. Give and take for the Batak tribe is a unity.

According to ancient tradition, the practice of mangadati is carried out simply. The ceremony can be carried out simply because it is held in the yard and is done in mutual cooperation. The Dalihan na tolu system is very instrumental with the help of neighbors (dongan sahuta). The nature of mutual cooperation becomes the main requirement in the implementation of traditional ceremonies. Through mutual cooperation that they do, all the burden becomes light.

The nature of mutual cooperation which is fading from day to day has an impact on the implementation of a more expensive marriage ceremony. Rich people invite many people and hold a wedding ceremony in a luxurious place. This is done by the rich to show class in society as Bourdieu (1984) intended. The rich supply new things, branded objects with the aim of establishing a distance between the rich and the poor. On the other hand, the poor pursue the needs of the rich (Featherstone, 2008: 43).

The distance attempt by the rich in the marriage ceremony will be followed by the poor. In a short time the lower classes followed the tastes of the upper classes. The distance establishment efforts carried out by the upper classes and the imitation of lower class consumption efforts have led to a more consumerist marriage ceremony. Consumerism becomes a lifestyle that is produced continuously through signs, images, and symbolic meanings.

The most recent procession of the Batak marriage ceremony is paulak une and tingkir tangga. Paulak une is derived from paulak which is to restore and une is good. The meaning of Paulak Une is to return or tell everything is good. The party doing Paul une is a family of men who come to the family of women. The purpose of the visit was to show respect for the man towards the woman that his daughter was in good condition (still a virgin).

After the men visited the house of the woman, the woman returned the so-called maningkir ladder. Literally, maningkir is seeing, and tingkir are stairs. Therefore, the stairs upside down is a return visit from the parents of the female party to the parents of the male family. The woman's parents know the house and know the social and economic situation of the daughter of her newly married daughter.

According to ancient tradition, the paulak une and maningkir tangga are held a few days after the wedding ceremony. When the marriage ceremony takes place at the place of the male family, it is called a taruhon jual. The meaning of the word taruhon is delivered and jual is sold. When the marriage ceremony takes place at the place of the male family, the female family automatically recognizes the house of the male family so that the procession of the tinggkir tangga is no longer needed but the paulak une must be carried out.

If a marriage ceremony is held at a place of woman's family, it is called dialap jual. The meaning of the word dialap is being picked up and jual is for sale. Because the marriage ceremony was held at the place of the women's parents, it was unnecessary for paulak une to do so. However, the procession of maningkir tangga must be carried out.

Different today, the two processions above (paulak une and maningkir tangga) are all carried out together which are combined on the peak day of the wedding ceremony. Instant factor, do not want to be bothered, want an instant result in the meaning of Paulak Une and Maningkir tangga is lost. Wedding ceremonies are dominated by frenetic music and singers. The success of the ceremony is interpreted through external appearances while the actual meaning is sidelined. External appearance filled with excitement requires very much cost. 


\subsection{Forms of Consumerism in the Batak Toba Marriage Ceremony}

Consumerism that occurs in the Batak Toba marriage ceremony takes several forms, namely, mindset, action, and material. Each individual in carrying out daily activities is determined by what is in his mind. The mind is decisive in acting. A person's mindset is influenced by the mindset of the society in which he lives, on the contrary, the mindset of a society is determined by the mindset of each individual. Koentjaraningrat (2015a) concluded that the mindset of individuals and groups (communities) influenced each other.

Group mindset is one of the three forms of culture as expressed by Koentjaraningrat (2015b). According to Koentjaraningrat, culture has three forms, namely ideas, actions, and results (material). The mindset of humans into abstract ideas, cannot be touched or photographed because they are in the minds of the people concerned. Mindset can be known through words, writing that can be stored in the form of books or other tools.

The culture of ideas functions as a code of conduct that regulates, controls, and gives direction to human behavior in society. The code of conduct is interrelated with one another and is called the cultural system. Customs become institutions that regulate society to act in everyday life. However, customs are not innate as stated by Barker (2004: 39) but the result of the construction of the community.

The marriage ceremony is a Batak Toba custom that every family should do. The marriage ceremony becomes a very necessary thing because to be able to enter into the Dalihan na tolu system, one must first perform the marriage ceremony. Initially the implementation of the ceremony was carried out in mutual cooperation by using elements of Dalihan na tolu. Each element supports one another and cannot be exchanged.

The entry of globalization changed the mindset of the Batak Toba tribe in holding a marriage ceremony. Globalization as said by Piliang (2011: 235), creates cultural homogenization into global culture. The Batak consume an instant and efficient mindset that does not belong to them. Togetherness and togetherness are replaced by new thought patterns, namely differences and individualism.

In ancient society, marriage ceremonies were carried out in the same form. In addition to the same form, the implementation is also carried out together. Togetherness in question is the element Dalihan na tolu plays an active role together, not just one element. Dongan tubu and boru worked together to bear the costs of the ceremony, while the hula-hula gave the blessing.

At present, especially in urban areas, togetherness and similarity are outdated and replaced by the creation of differentiation continuously through the mechanism of signs, images, and symbolic meanings. As said by Piliang (2011: 238), the culture of consumerism is related to the urban environment, because in cities spaces for consumption are constantly being built. Because the facilities are very complete for consumption, the community is constructed as a consumerist society. The differential mindset which is a product of outside culture is also consumed by Bataks in marriage ceremonies. They try to make new and different from others who are usually better and more expensive so that from day to day, marriage ceremonies are increasingly consumerist.

Consumerism of the Batak Toba marriage ceremony also occurs in the behavior. Behavior is driven by one's mindset. The behavior of a person is influenced by the behavior of the community while the behavior of the community is determined by the behavior of each individual.

Regarding behavior, the ancient Batak people had a philosophy of caution. This can be seen from the phrase: manat unang tartuktuk, dadap unang tarrobung. The meaning of this expression is to be careful not to stumble, slowly so as not to fall. Caution is a priority when acting while doing everything in a hurry which done by Batak Toba tribe must be avoided.

Actions that avoid this thing can be seen from the phrase: nai humalaput Tata indahanna, nai humarojor mabola hudonna. This parable has meaning, people who rush to cook rice will not produce good results, it can be raw or even the pots will break. Any hasty action will bring unexpected results. Therefore, the Batak people avoid instant action. Unlike in ancient societies Batak tribes today have abandoned their cautious behavior and have been replaced with practicality and instantaneous. As stated by Piliang $(2011: 232)$ that the world of human life in the present is controlled by time and speed in doing anything. This factor causes humans to be dissolved in the speed of production, consumption, industry and loss of space such as space for reflection, contemplation, meditation or spirituality.

Everything which is practical or instan that is accustomed to being done in a marriage ceremony can be seen from the determination of the place of the marriage ceremony. At the present time before the marhusip and marhata sinamot, the place and day of the ceremony were unilaterally determined. Marhusip secrecy between male parents and female parents is lost. The sacredness of marhata sinamot is lost, replaced with pretense. The loss of confidentiality is replaced by pretense due to the practility factor or things which are instant. 
Usually for the Batak people to determine the day of the ceremony and its location discussed together. This agreement was obtained at the time of Marhata sinamot. The limitations of the building for the location of the ceremony, so that the Batak tribes competing to find what they want. Such a place is so limited that it must be sought in advance before the wedding ceremony. If there is an appropriate location then proceed with marhusip and marhata sinamot.

The attitude of wanting to be fast, do not want to bother becoming a habit in the Batak tribal wedding ceremony. This attitude can be seen from the behavior of renting ceremonies and catering orders. The Dalihan na tolu system, which the Bataks are always proud of, is currently experiencing a setback. For example, the behavior that is instant and does not want to bother leaving a sense of mutual cooperation. Behavior that is always looking for the instant continuously results in consumerism in behavior.

In addition to consumerism in thought patterns and behavior, consumerism is very clearly seen in material. Especially in urban communities, humans have been controlled by matter. The subject is mastered even subject to the object (Piliang, 2011: 233). In this case, humans are subjected to objects so human existence is determined by status, prestige and class. Humans dissolve into surface culture, appearance, image, lifestyle that prioritizes material culture.

Initially, in the area of origin the implementation of the wedding ceremony took place simply. Subsequent developments made simplicity abandoned and replaced with luxury and excitement. The upper class consumes objects excessively to show its class, while the lower class tries to consume the upper class object. Veblen's imitation of the lower class is called flowing downward (Wiedenhoft, 2012: 825).

Consuming different objects is one of the ways in which the upper classes keep their distance from the lower classes. Instead the lower classes try to catch up with the class even though they never liked it. This competing behavior resulted in Batak tribal wedding ceremonies being dominated by material.

Some examples of objects that dominate the Batak marriage ceremony are big cakes, decorative flowers, and souvenirs. The object of the cake has nothing to do with the marriage ceremony. However, due to wedding ceremonies in big cities, cakes are often used in hotels so that the objects of cake that are commonly used for birthday cakes are consumed as packages for the wedding ceremony.

Likewise, room decoration objects are filled with flowers, both live flowers and artificial flowers. The flower markers used in the wedding ceremony decoration have exceeded the actual markings. Flowers are often identified with love and the symbol of beauty, but in the Batak Toba marriage ceremony the sign of flowers is not just beauty and love. The flower sign changes meaning luxury. It is true what Derrida said (1974: 7) that there is always a gap between the signifier and the signifier, between the text and its meaning. The sign becomes an object that is very necessary in the Batak Toba marriage ceremony.

\subsection{Factors Affecting Consumerism}

There are several factors causing the Batak Toba marriage ceremony to become more and more consumerist. The most dominant factor is globalization, lifestyle, popular culture and a lack of understanding of the meaning of the Batak Toba marriage ceremony. Each of these factors is interrelated and mutually supportive. Globalization is the process of integrating various elements of the living world into a single system on a world scale (Piliang, 2011: 22). Globalization occurs due to the globalized nature inherent in the institutions of modernity. Giddens termed the institutions of modernity with juggernaut that went out of control and wiped out everything that got in the way (Barker, 2014: 110).

Globalization factors influence the practice of Batak Toba marriage ceremonies, for example serving food at a buffet ceremony. The buffet method is known in Europe, but the Batak people consume this method in marriage ceremonies. It seems that the buffet method is very practical but behind its practicality there is a capitalist ideology that permeates it. The buffet system eliminates mutual cooperation and fosters a sense of individualism. The Dalihan na tolu degraded system is replaced by homo individualists. Globalization changed the culture of mutual cooperation Batak tribe into individualist culture.

Another factor is lifestyle. Lifestyle is a way for everyone to interpret his life through things. Lifestyle becomes one of the social distinctions in people's lives (Piliang, 2011: 322). Lifestyle involves: capital, objective conditions, habitus, disposition, practice, sign system, and taste structure. Lifestyle is a product of habitus that is systematically produced through habitus schemes and practices (Bourdieu, 1984: 170-173).

The rich Batak tribe conducts wedding ceremonies in a way that is more often than others have done. This behavior needs to be done to maintain the position that is already owned. It is a taboo for the Batak people if the upper classes hold a wedding ceremony in a simple manner. To maintain the existence of the class, they make a lifestyle 
that is different and more luxurious than usual. The lower class does not want to be outdone by the upper class lifestyle. The lower classes try in various ways to pursue the objects of upper class needs. The upper class lifestyle consumes new material that the lower classes will follow by imitating the consumption of the upper class. The different lifestyles exhibited by the upper classes and those of the lower classes pursuing upper class consumption make the Batak Toba marriage ceremony more and more consumerist.

Consumerism is also related to popular culture because in popular culture there is a capitalist ideology. Culture was created as part of the logic of markets and commodities. Culture is constructed based on the principle of difference; appearance, style, and lifestyle that are created always change in a very fast time (Piliang, 2011: 415). The community is concerned with the value of signs and symbolic values rather than use values and exchange values. Appearance is more important than depth, pleasure is more important than solemnity and style is more important than essence.

Popular cultural practices that dissolve in the Batak Toba wedding ceremony can be seen from the objects consumed during the ceremony. Ranging from small things in the form of souvenirs, wedding cars, wedding dresses, entertainers, caterers to the venue of the ceremony filled with marks. The value of the sign contained in the objects above often exceeds the use value so that the object becomes a fake.

Souvenirs have nothing to do with the Batak Toba marriage ceremony, but in reality everyday seems to be a necessity. The bridal car is not only useful as transportation is preferred over the mark value by using expensive branded cars. The wedding dress is only used once in his life, but must be purchased at an expensive price. Artists and music are not related to ceremonies, but to pursue excitement become a basic necessity. Caterers get the largest portion of expenditure because the process is not mutual cooperation but order. The place to hold the ceremony is not just any place, but it must be a large building with complete facilities.

An equally important factor that also influences consumerism in the Batak Toba marriage ceremony is a lack of understanding of the tradition. Culture is not a gift but a result of construction. In culture as Marx said (1961: 92) it is always political and in it there are power relations. Therefore culture is not a kind of holy book whose nature does not need to be questioned but culture must always be improved in a better direction all the time.

The practice of the Batak Toba marriage ceremony today is mostly done because of ignorance. They are absorbed in consumerism because they have joined with the surrounding community. This ignorance is evident from the parable: eme na masak digagat ursa, ia i na masa ima niula. This parable means doing something because someone else has already done something like that.

Consumer society as said by Piliang (2011: 417) is a spectacle community. Community existence is found through its appearance in the midst of society. The practice of marriage ceremonies is an arena for Batak tribes to find their existence. The Batak people demonstrate their abilities to other people while those who watch imitate them without understanding what the meaning is. The desire to watch others and show themselves causes the marriage ceremony to be increasingly consumerism.

\section{Discussion}

\subsection{Culture Profile of Batak Toba}

Batak tribes have sub-ethnic groups namely, Toba, Simalungun, Pakpak, Karo, Angkola and Mandailing. Each of these sub-tribes has a native area: Batak Toba, inhabiting around the shores of Lake Toba, Samosir Island, Asahan, Silindung, Barus, Sibolga, Pahae, and Humbang; Simalungun Batak, living in the Simalungun area; Batak Pakpak, inhabiting Dairi; Karo Batak, inhabiting Tanah Karo, Langkat Hulu, Deli Hulu, Serdang, and parts of Dairi; Angkola Batak, inhabiting Angkola and Sipirok, a part of Sibolga, Batang Toru, and Padang Lawas; and Mandailing Bataks, inhabiting Mandailing, Ulu, Pakatan and parts of Padang Lawas. Each sub-tribe has its own language and distinctive accent.

In everyday life, from each Batak sub-tribe, the usual use of mentioning the Batak tribe is the Batak Toba. Other Batak tribes are more commonly called the Simalungun tribe, Karo tribe, Pakpak tribe, Mandailing tribe, and Angkola tribe. Likewise the mention of "Medan people" refers to the Batak Toba's people, whereas in Medan the Batak Toba's people are not the majority or indigenous people.

According to the sacred stories of the Batak people (tarombo) that are still believed to this day, all Batak people are descendants of Si Raja Batak and first settled at the foot of Pusuk Buhit Mountain in Sianjur Mulamula, Samosir Regency, North Sumatra Province (Sinaga, 1997: 40). Because the population is increasing while the food source is very limited, this causes the descendants of Si Raja Batak to migrate. The first destinations for them to migrate were the Humbang, Simalungun, Karo, Mandailing and Pakpak areas. As a result of this migration, subtribes of the Batak tribe emerged. 
The migration of Batak people from their hometown to other region does not change their kinship system. The Batak tribe counts offspring in a patrilineal way, wherever they are based on: one father, one grandfather or one ancestor (Bangun, 2004). It is a must for the adult Batak people to be able to explain their ancestral pedigree to themselves. To find out this genealogy each clan wrote it which was then called the tarombo. Only men who have the right to enter the tarombo are married.

The embodiment of the pedigree for the Batak people can be seen from the inclusion of the clan of the father behind his own name. As stated by Bruner (2017:223), clans show a kinship group that includes people who have a common ancestor and may not marry each other. Besides showing kinship, the clan for the Batak people is a pride so they prefer to be called a clan than their name.

The ideal marriage for the Batak tribe is marpariban (matrilateral cross cousin). An adult Batak man will marry his mother's brother's daughter. This system is standard and should not be reversed and even must be passed on to the next generation. This is consistent with what Castles (2001: 7) stated with the marpariban marriage system, a kinship network will be formed as well as completing lineage and lineage.

Marpariban marriage is considered to be an ideal system because the position of the female giver, in regional languages is called hulahula higher than the position of the receiving party, which is referred to as boru. The position of hulahula and boru does not only apply during traditional ceremonies, but also applies in daily life. To maintain the regular social relations, it is required that every male Batak tribe marries his mother's brother's daughter.

In terms of numbers, marpariban marriages for Batak tribes have increasingly declined both in the area of origin and overseas. Even though a man does not marry his mother's brother's daughter directly, the Batak people consider her to be still marpariban. A newly married woman enters the family of her mother's brother's family. Thus for the Batak tribe every woman who is married is a pariban.

According to ancient tradition, the Batak do not know mixed marriages. Mixed marriages are difficult to accept because they are related to the Dalihan na tolu system. Dalihan na tolu is a system that regulates kinship between one another. People who can enter this system are Batak people who have already been married. All people who are not Batak are considered foreigner which in local language is called sileban.

The entry of zending into the Tapanuli region on October 7, 1862 opened new insights for the Batak tribe towards people outside their tribes. As Schreiner (2002) put it, zending succeeded in the Tapanuli region because the missionary message carried out by missionaries was accompanied by development in the fields of education, health, and the economy. Development in the field of education resulted in changes in the exclusive attitude to be inclusive towards outsiders.

Batak people who marry outside their tribes are no longer seen as stranger but outsiders are included in the kin system. The method is, if the woman comes from outside the Batak tribe, then the woman is first included in the clan of her mother's brother (tulang). Conversely, if the man comes from outside the Batak tribe, the man is included in the clan group husband of his father's sister (amangboru). The entry of outsiders into the kinship system of the Batak tribe results in every person who marries a permanent marpariban and enters the dalihan na tolu system.

The Bataks do not recognize social stratification such as the aristocracy and the commoners. The differences that exist in their lives are based on age, rank and position of work, the nature of authenticity and marital status (Bangun, 2004). For Batak people, only those who have the right to give an opinion in a traditional ceremony are married. Likewise in the distribution of inheritance, only people who are married have the right to get it.

The social coating system based on rank and daily work is very clearly seen in simple society. The most respected layers are shamans, artisans and musicians (pargonsi). This profession is highly respected because it requires special expertise. These three professions can be done by someone because they are considered to have magic power. The difference between indigenous people and migrants also make the Batak tribal coating system. Newcomers who want to hold traditional ceremonies must first ask permission from the native population in the village. If the natives do not allow it, the ceremony will be canceled. Therefore, every newcomer must respect the native population.

Another coating system is based on marital status. Unmarried people regardless of their age are classified as groups of children. Because they are still a group of children, they cannot hold all the traditional ceremonies. Unmarried people do not get inheritance from their parents. In addition, they also cannot be included in the pedigree (tarombo). 


\subsection{Dalihan Na Tolu System}

Dalihan na tolu is a family system that exists in the Batak tribe that regulates the relationship between one another. Through the interruption of the relationship, every Batak person will be well organized in traditional ceremonies and also in everyday life. Batak people are very proud to have a Dalihan na tolu so that they continue to preserve it. In the Dalihan na tolu system, the Batak tribe do not know caste but equality between one and the other. For the Batak tribe, every man is a king's child and every woman is a princess. There is no one person or group occupying a position always more high, but the position was alternating with other words, the third position was occupied by every Batak (Siregar, 2017: 13).

Literally, dalihan is a furnace, na tolu means three. From this understanding it can be concluded that the Dalihan $n a$ tolu is a stove made of three stones which support each other. This tradition was carried out in ancient society to cook food. Furnace (dalihan) can function well if it consists of at least three stones.

The philosophy of the Dalihan na tolu is manifested in the kinship relations of the Batak tribe, namely dongan tubu, hula-hula, and boru. Dongan tubu is a clan, hula-hula is a clan group giving a wife while boru is the recipient of a wife. Every Batak person will enter into the system of Dalihan na tolu. For the details, it can be seen like the picture below:

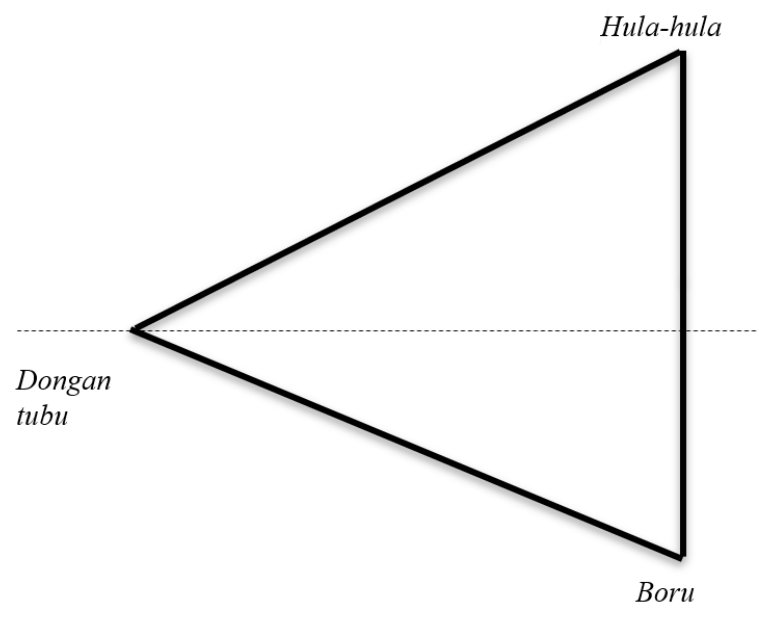

Figure 1. Dalihan na tolu

Doc. Mangihut Siregar, 2019

In the picture above you can see three elements that support each other to form a triangle. The first element is the hula-hula which is at the top. For the Batak tribe, the hula-hula is a symbol of God giving blessings. In addition to giving blessings, hula-hula is the giver of wives whose role is to provide offspring to the group of men. Hulahula is such a noble position, that the Batak people are very respectful and obedient to the hula-hula with their group.

In the middle there is a dotted line showing the position of the dongan tubu or often also called dongan sabutuha which has a neutral position. Groups included in this group are, brother, sister, father, grandfather, children, grandchildren who have the same clan. All groups of one clan regardless of their background, if they are included in the Dalihan na tolu system, their position is equal.

The lowest position in the Dalihan na tolu system is the boru group so that in the picture above it is the lowest position. Boru's position got the lowest position because the woman went out to her husband's clan group. Even though their position is the lowest, in the practice of traditional ceremonies their roles are numerous. Boru group is tasked with doing all the ceremonial needs and also as the backbone in the financing of the ceremony.

The picture above shows the position of each, where the position of hula-hula, boru and dongan tubu are different. The higher position is hula-hula and the lowest position is boru. However, none of these three elements are the most important and the least important, but each element is equally important. As stated Siahaan (1982: 52), the relationship between the three elements of Dalihan na tolu needs to be maintained so that all the traditional ceremonies found in the Batak Toba tribe can be carried out perfectly. The perfection of traditional ceremonies is measured by the completeness and good relations between boru, dongan tubu and hula-hula. 


\subsection{Consumerism with the Purpose of Life}

The Batak tribe has three life goals namely, hagabeon, hamoraon and hasangapon. Hagabeon is obtained through offspring. The more offspring the more perfect the hagabeon he has. Many descendants become one of the goals of life because offspring is a capital to continue generations, a source of energy to cultivate agricultural land and strength to defend themselves from enemy attacks. Once the importance of having many offspring so that the Batak tribe made it one of his life goals.

The second purpose of life is hamoraon or treasure. In ancient society, hamoraon was measured by the number of pets (buffalo, horse, cow and pig) owned and the many harvests. Animals become a valuable treasure because they are very useful for cultivating agricultural land. In addition to energy to cultivate agricultural land, animals are also used during traditional ceremonies. Agricultural products become daily food.

The ultimate goal in life is hasangapon or honor. Someone get hasangapon usually when the first life goal and the second has been achieved. It is impossible to get hasangapon if you don't have a son. Likewise regarding wealth, will not get the honor if his life in poverty. Hasangapon obtained when his life to perfection. Therefore, Hasangapon is the highest goal of life for the Batak tribe.

The Batak have a purpose in life only in the world, whereas the here after is of little concern. This can be seen from the purpose of their lives only hagabeon, hamoraon and hasangapon. Life after the world is ruled out. Because the purpose is only in the world so that their spiritual life is less than worldly life.

The elements of hagabeon, hamoraon and hasangapon are the capital in the life of the Batak tribe. As Bourdieu said (1977: 178), capital consists of various kinds namely cultural capital, economic capital and symbolic capital. Hagabeon is identical with cultural capital, hamoraon is identical to economic capital while hasangapon goes to symbolic capital.

Capital must exist in every domain, so that it has meaning. One's legitimacy in daily life is influenced by how much capital he has. Capital in practice can be accumulated and can also be exchanged. The greatest change is to get symbolic capital. Symbolic capital is interpreted as something legitimate (Harker, 2009: 17).

The symbolic capital for the Batak is hasangapon. To get hasangapon, the rich exchange their economic capital. This exchange is common in the practice of marriage ceremonies. Poor people don't want to be inferior to rich people. Little economic capital is also exchanged for the poor to reach hasangapon. For rich people, spending a lot of money to conduct a marriage ceremony is common. Through marriage ceremonies, rich people have the opportunity to accumulate economic capital with symbolic capital.

Capital exchange by the rich and the poor in order to achieve the goals of Hasangapon life has made the cost of the marriage ceremony more expensive The Batak Toba tribe is aware of the consumerism practice of marriage ceremonies. Consumer behavior has become a problem, but they still do it. Consumerism on the one hand becomes a problem, on the other hand becomes an arena to achieve life goals.

\subsection{Conclusion}

The marriage ceremony is a tradition that really needs to be done by the Batak Toba tribe. Through marriage ceremonies they may enter into the Dalihan na tolu system. In the Dalihan na tolu system each individual has a clear position both as dongan tubu, boru, and hulahula. All three of these positions have the same functions necessary. If one of the elements from Dalihan na tolu is incomplete, the traditional ceremony performed will be flawed. Therefore, the Batak people always maintain a good relationship between boru, dongan tubu and hulahula. Apart from being a bridge to enter Dalihan na tolu, marriage ceremonies also function to be able to carry out life cycles such as welcoming newborn children, marriage, death, entering the house, and others. Another benefit of marriage ceremonies is towards maturity. For Bataks, unmarried people are considered children. Children have no right to make decisions in the family; not entitled to inheritance; and not yet included in the pedigree (tarombo). It was so important for the Batak tribe to hold a marriage ceremony so that they still maintain the tradition.

The practice of marriage ceremonies today is filled with consumerism. Consumer behavior occurs in all places both in the village, especially in urban areas. This habit can be observed through the amount of cost spent and the long duration of time in each ceremony. Batak people consume objects not only based on use value and exchange value but also prioritize the value of signs and symbolic values. Consumerism happens not only in matter but also in thought and behavior.

Consumerism in the mindset that occurs is to leave the similarity and togetherness replaced the nature of individualism and differences. Consumerism in behavior takes the form of practice and does not want to be bothered. Capitalism is increasingly rampant while mutual cooperation has been swallowed up by globalization. 
Consumerism in this case is a problem, but on the other hand consumerism becomes an arena to achieve hasangapon life goals.

In connection with consumerism that took place in the Batak Toba marriage ceremony, it was suggested that there would be collaboration between the church, traditional leaders, community leaders and local government in North Sumatra to overcome them. It's time to review the meaning contained in each procession of the Batak Toba marriage ceremony. Actions that is easy to do can be in the form of seminars, discussions, counseling, research, and so on. Through the excavation of ceremonial meanings, it is hoped that the Batak tribe will not be mired in prolonged consumerism behavior.

\section{References}

Bangun, P. (2004). “Kebudayaan Batak” (pp. 94-116) in Manusia dan Kebudayaan di Indonesia, Koentjaraningrat, editor, Jakarta: Djambatan.

Barker, C. (2004). Cultural Studies Teori \& Praktik. (Nurhadi Trans.). Yogyakarta: Kreasi Wacana.

Barker, C. (2014). Kamus Kajian Budaya. (B. Hendar Putanto Trans.). Yogyakarta: Kanisius.

Bourdieu, P. (1977). Outline of a Theory of Practice. Cambridge: Cambridge University Press. https://doi.org/10.1017/CBO9780511812507

Bourdieu, P. (1984). Distinction: A Social Critique of the Judgement of Taste. Harvard: University Press.

Bruner, Edward. (2017). "Kerabat dan Bukan Kerabat" (pp. 203-230) in Pokok-pokok Antropologi Budaya, T.O. Ihromi, editor, Jakarta: Yayasan Pustaka Obor Indonesia.

Castles, L. (1972). The Political Life of A Sumatran Residency: Tapanuli 1915-1940. Michigan: Xerox Univ. Microfilm.

Derrida, J. (1974). On Grammatology. Baltimore: John Hopkins.

Featherstone, M. (2008). Postmedernisme dan Budaya Konsumen. (Misbah Zulfa Elizabeth, Trans.). Yogyakarta: Pustaka Pelajar.

Harker, R., Cheelen, M., \& dan Chris, W. (2009). "Posisi Teoretis Dasar" (pp. 1-32) in (Habitus x Modal) + Ranah $=$ Praktik Pengantar Paling Komprehensif kepada Pemikiran Pierre Bourdieu, Richard Harker, et al., editors. (Pipit Maizier, Trans..) Yogyakarta: Jalasutra.

Hutauruk, J. R. (2011). Lahir, Berakar dan Bertumbuh di dalam Kristus: Sejarah 150 Tahun Huria Kristen Batak Protestan (HKBP) 7 Oktober 1861 - 7 Oktober 2011. Tarutung: HKBP Head Office.

Koentjaraningrat. (2015a). Pengantar Ilmu Antropologi. Jakarta: Rineka Cipta. https://doi.org/10.7454/ai.v0i47.3271

Koentjaraningrat. (2015b). Kebudayaan Mentalitas dan Pembangunan. Jakarta: Gramedia.

Lubis, A. Y. (2014). Teori dan Metodologi Ilmu Pengetahuan Sosial Budaya Kontemporer. Jakarta: Rajawali Pers. Martono, N. (2015). Metode Penelitian Sosial: Konsep-konsep Kunci. Jakarta: Rajawali Pers.

Marx, K. (1961) Karl Marx: Selected Writing in Sociology and Social Philosophi, editor T. Bottomore and M. Rubel. London: Pelican.

Moleong, L. J. (2014). Metodologi Penelitian Kualitatif. Bandung: PT Remaja Rosdakarya.

Pelly, U. (1994). Urbanisasi dan Adaptasi Peranan Misi Budaya Minangkabau dan Mandailing. Jakarta: PT Pustaka LP3ES.

Piliang, Y. A. (2011). Dunia yang Dilipat: Tamasya Melampaui Batas-batas Kebudayaan. Bandung: Matahari.

Schreiner, L. (1972). Adat und Evangelium: Zur bedeutung der altvolkischen Lebensordnungen fur Kirce und Mission unter den Batak in Nordsumatra. Guttersloh: Gutterslocher Verlagshaus Gerd Mohn.

Simanjuntak, I. (2011). "Pesta Adat di Kalangan Suku Batak Toba yang Beragama Kristen”(in Pemikiran tentang Batak: Setelah 150 Tahun Agama Kristen di Sumatera Utara. Bungaran Antonius Simanjuntak, editor, Jakarta: Yayasan Pustaka Obor Indonesia.)

Sinaga, R. (1997). Leluhur Marga-Marga Batak dalam Sejarah, Silsilah dan Legenda. Jakarta: Dian Utama.

Siregar, M. (2018). Ketidaksetaraan Gender dalam Dalihan na tolu. Jurnal Studi Kultural, Vol. III No. 1: 13-15.

Wiendenhoft, W. (2012). "Teori-Teori Konsumsi” (pp. 817-849) in Handbook Teori Sosial, George Ritzer \& Barry Smart, editors. (Imam Muttaqien, et al. Pentj). Jakarta: Nusa Media.

\section{Copyrights}

Copyright for this article is retained by the author(s), with first publication rights granted to the journal.

This is an open-access article distributed under the terms and conditions of the Creative Commons Attribution license (http://creativecommons.org/licenses/by/4.0/). 